\title{
Cold agglutinins in patients undergoing cardiac surgery requiring cardiopulmonary bypass
}

\author{
David W. Barbara, MD, ${ }^{\mathrm{a}}$ William J. Mauermann, MD, ${ }^{\mathrm{a}}$ James R. Neal, CCP, ${ }^{\mathrm{b}}$ Martin D. Abel, MD, ${ }^{\mathrm{a}}$ \\ Hartzell V. Schaff, MD, ${ }^{b}$ and Jeffrey L. Winters, MD $^{c}$
}

\begin{abstract}
Objectives: Cold agglutinins (CA) are circulating autoantibodies present in most humans. They are active below normal body temperatures. Cold hemagglutinin disease involves the presence of CA sufficiently active at temperatures in the periphery to produce hemolysis or agglutination. Systemic hypothermia and cold cardioplegia may result in agglutination or hemolysis. We reviewed the experience of a large referral center in managing patients with CA and cold hemagglutinin disease undergoing cardiac surgery requiring cardiopulmonary bypass.
\end{abstract}

\begin{abstract}
Methods: The electronic medical records from 2002 to 2010 were searched to identify patients with CA or cold hemagglutinin disease who underwent cardiac surgery requiring cardiopulmonary bypass. Information related to preoperative $\mathrm{CA}$ testing and treatment, surgery, cardiopulmonary bypass, postoperative complications, and mortality was recorded.

Results: Sixteen patients underwent 19 procedures requiring cardiopulmonary bypass. Six patients had cold hemagglutinin disease. The identification of CA was made intraoperatively in 3 patients. One patient underwent preoperative plasma exchange. Cold blood cardioplegia was used in 2 of 16 procedures using cardioplegia, with the remaining using warmer blood cardioplegia. The lowest recorded intraoperative core temperature was less than $34^{\circ} \mathrm{C}$ in 1 case. CA-related postoperative hemolysis requiring transfusion was present in 1 patient, which was resolved with active warming. No patient had evidence of permanent myocardial dysfunction, had a neurologic event, required dialysis, or died within 30 days.

Conclusions: All patients with CA/cold hemagglutinin disease at the Mayo Clinic College of Medicine safely underwent cardiac surgery without major adverse morbidity or mortality. Patients with CA but without evidence of cold hemagglutinin disease can safely undergo normothermic cardiopulmonary bypass at $37^{\circ} \mathrm{C}$ and warm cardioplegia without further testing. Patients with cold hemagglutinin disease should undergo laboratory testing including CA titers and thermal amplitude and hematology consultation before cardiac surgery. (J Thorac Cardiovasc Surg 2013;146:668-80)
\end{abstract}

Cold agglutinins (CA) are autoantibodies that become active at temperatures below physiologic body temperature. These antibodies are present in most humans but are rarely of clinical significance because they do not react at temperatures that are normally seen by the blood. ${ }^{1}$ Cold hemagglutinin disease (CHAD) is characterized by the formation of CA that are sufficiently active at temperatures achieved in the peripheral circulation, such as the distal extremities on exposure to cold, allowing hemolysis or agglutination to occur. $^{2,3}$

It is important to distinguish between CA and CHAD in that one represents a benign variant of normal and the other is a pathologic process. The benign and pathologic autoantibodies are directed toward the same common red blood cell

From the Departments of Anesthesiology, ${ }^{\mathrm{a}}$ Cardiovascular Surgery, ${ }^{\mathrm{b}}$ and Laboratory Medicine and Pathology, ${ }^{\mathrm{c}}$ Mayo Clinic College of Medicine, Rochester, Minn. Disclosures: Authors have nothing to disclose with regard to commercial support.

Received for publication Dec 10, 2012; revisions received Jan 28, 2013; accepted for publication March 6, 2013; available ahead of print April 15, 2013.

Address for reprints: William J. Mauermann, MD, Mayo Clinic, 200 First St SW, Rochester, MN 55905 (E-mail: mauermann.william@mayo.edu).

$0022-5223 / \$ 36.00$

Copyright (c) 2013 by The American Association for Thoracic Surgery

http://dx.doi.org/10.1016/j.jtcvs.2013.03.009 antigens, most commonly IH, I, or i, but differ in that the benign autoantibodies are usually polyclonal, cause agglutination or complement fixation at less than $25^{\circ} \mathrm{C}$, and have titers less than 64 at $4^{\circ} \mathrm{C}$ and less than 16 at $22^{\circ} \mathrm{C}$. The antibodies in CHAD are usually monoclonal, cause agglutination or complement fixation at $30^{\circ} \mathrm{C}$ to $37^{\circ} \mathrm{C}$, and have titers greater than 512 at $4{ }^{\circ} \mathrm{C}$ and greater than 128 at $22^{\circ} \mathrm{C}^{1}$

CHAD is responsible for $16 \%$ to $32 \%$ of all autoimmune hemolytic anemias in both children and adults, with an estimated prevalence of 10 to 16 cases per 1 million people..$^{3-5}$ With rare exception, CHAD almost exclusively involves immunoglobulin-M autoantibodies. ${ }^{3,6}$ The CA present in CHAD bind to red blood cells at the colder temperature of the peripheral body (eg, hands, feet, ears, and nose), causing agglutination and complement fixation. Because of the cooler temperatures, complement cannot activate but remains on the red cell surface. On rewarming in the body's core, the CA release, but complement in the form of $\mathrm{C} 3 \mathrm{~b}$ remains on red blood cells. Extravascular hemolysis occurs predominantly in the liver as the complement-coated red blood cells are removed by macrophages. ${ }^{2,7}$ The severity of CHAD varies greatly among patients according to antibody titer and thermal activity of the CA. Although CA do not 


\section{Abbreviations and Acronyms \\ $\mathrm{CA}=$ cold agglutinins \\ $\mathrm{CHAD}=$ cold hemagglutinin disease \\ $\mathrm{CPB}=$ cardiopulmonary bypass \\ IABP $=$ intra-aortic balloon pump}

typically react at temperatures greater than $30^{\circ} \mathrm{C}$, Rosse and Adams ${ }^{8}$ report patients with CHAD antibodies active at normothermia $\left(37^{\circ} \mathrm{C}\right)$. CHAD may be a primary disorder or be secondary to malignancy (most commonly lymphoma), infection (infectious mononucleosis or Mycoplasma pneumonia infection), or autoimmune diseases. ${ }^{2-4}$

Cardiac surgery requiring cardiopulmonary bypass (CPB) and hypothermia carries a significant risk of morbidity in patients with CA or CHAD. Systemic hypothermia and cold cardioplegia may result in blood reaching temperatures that can cause agglutination and hemolysis. ${ }^{9,10}$ Hemolytic anemia ${ }^{11}$ and myocardial dysfunction ${ }^{12}$ have been attributed to $\mathrm{CA}$ in patients undergoing hypothermic $\mathrm{CPB}$, whereas dysfunction of other end organs secondary to $\mathrm{CA}$ is a hypothetical concern. ${ }^{3,9}$ Experience involving patients with CA and CHAD undergoing cardiac surgery requiring CPB consists of case reports and small series, ${ }^{9,12}$ of less than 20 cases that do not distinguish patients with CA from those with CHAD and case reports of patients with CA and CHAD. The purpose of this study was to review the recent experience of a single large tertiary referral center in managing patients with $\mathrm{CA}$ or $\mathrm{CHAD}$ undergoing cardiac surgery requiring $\mathrm{CPB}$.

\section{MATERIALS AND METHODS}

This study was approved by the Mayo Foundation Institutional Review Board. A computer-generated search of the electronic medical records from 2002 to 2010 (the time period from the implementation of the electronic anesthesia record to the end of the searchable patient records at initiation of this study) was performed to identify patients aged 16 years or greater with a diagnosis of $\mathrm{CA}, \mathrm{CHAD}$, or related diagnoses, such as cold autoimmune hemolytic anemia, cold hemolysis, and paroxysmal cold hemoglobinuria, who had given permission for their medical record to be used for research. These patients were then cross-referenced for those who underwent surgery requiring $\mathrm{CPB}$. Individual patient records were then reviewed by one of the authors (D.W.B.) to verify the presence of $\mathrm{CA}$ or CHAD and surgery requiring $\mathrm{CPB}$.

A standardized data-collection form was used. Demographic information (age at time of surgery and gender) was recorded. The electronic medical records of each patient were reviewed for preoperative information related to the surgery (diagnosis and operation type) and CHAD or CA (method of diagnosis; timing of diagnosis in relation to surgery; presence of CHAD signs and symptoms, eg, anemia, hemolysis, acrocyanosis; cause of $\mathrm{CHAD}$, eg, infections, lymphoproliferative disorder, or unknown; presence of paroxysmal cold hemoglobinuria; CA antibody titer; CA thermal amplitude; direct antiglobulin test; hemoglobin; creatinine; whether valvular pathology was thought to contribute to hemolysis as indicated in physician notes; dialysis dependency; ejection fraction from transthoracic echocardiogram; lactate dehydrogenase; haptoglobin; and whether a hematologist was consulted before surgery). Details of treatments of CHAD within 90 days of surgery were recorded (plasma exchange; medical therapies, including rituximab, cyclophosphamide, chlorambucil, and glucocorticoids; intravenous immunoglobulin; history of splenectomy; erythropoietin; and transfusions). Generalized anesthetic information consisting of American Society of Anesthesiologists physical status classification and emergency or scheduled nature of surgery was noted. The intraoperative anesthetic record, surgical note, and perfusionist's record were reviewed for documentation of warming methods used; duration of $\mathrm{CPB}$; duration of aortic crossclamp; presence of circulatory arrest; cardioplegia techniques, including delivery method, temperature, composition, intervals, number of doses, and specific notations by the surgeon or perfusionist related to the cardioplegia; notations related to agglutination by the surgeon or perfusionist; nadir nasal and bladder temperatures; use of antifibrinolytics; and fluid and transfusion requirements. The postoperative record was reviewed for details of vasoactive medication or intra-aortic balloon pump (IABP) therapies as a marker of heart failure, transfusion requirements, aforementioned laboratory studies (including hemoglobin nadir and creatinine peak in the first 2 postoperative days), chest tube output in the first 48 postoperative hours, complications of transfusions as noted in the daily progress notes, and death within 30 days. Statistical analysis consisted of determination of mean \pm standard deviation, median, and range for continuous variables and quantification $(\%)$ for categoric variables.

\section{RESULTS}

We identified 16 patients with CA or CHAD who underwent 19 cardiac procedures requiring CPB. Of these 16 patients, 6 had evidence of CHAD before surgery (Appendix Table 1). Of the 10 patients with CA, 6 had CA identified at the time of preoperative type and screen at the Mayo Clinic College of Medicine or during CPB. The mean age at the time of surgery was $69 \pm 15$ years (median, 73 years; range, $16-81$ years), and 10 of $19(53 \%)$ were male. Details related to the $\mathrm{CA}$ or CHAD and preoperative testing are shown in Appendix Table 1. No patient had a history of paroxysmal cold hemoglobinuria. None of the surgeries were performed on an emergency basis. All procedures involved patients with American Society of Anesthesiologists physical status classification $3(74 \%)$ or $4(26 \%)$.

Preoperative treatment of CHAD or treatments that could have affected CA levels or CHAD included plasma exchange in 1 patient, glucocorticoids in 1 patient, and a history of splenectomy in 1 patient. Patient 1 underwent preoperative plasma exchange. A single 1.0 volume plasma exchange was performed using the COBE Spectra version 7.0 software (TerumoBCT, Lakewood, Colo) with ACD-A containing 7000 units of heparin as the anticoagulant. Replacement was $5 \%$ normal serum albumin with 3 units of fresh-frozen plasma at the end of the procedure. The choice of freshfrozen plasma as a replacement volume was made to replace coagulation factors before surgery. Patient 5 had received prednisone $20 \mathrm{mg}$ orally daily for 5 days preceding surgery for bronchitis and not to treat the CA. Patient 14 had a history of hemolytic anemia with the presence of both warm and cold autoantibodies. A splenectomy was performed months before cardiac surgery, with improvement in hemolysis after this intervention. Patient 2 was transfusion dependent before both surgeries because of ongoing hemolysis from CHAD 
and received 2 and 5 units of red blood cells before the first and second procedures, respectively.

The surgeries performed, intraoperative CA management, and fluid and transfusion requirements are detailed in Appendix Table 2. Mean duration of anesthesia was $315 \pm 102$ minutes (median, 302 minutes; range, 172541 minutes), CPB duration was $63 \pm 26$ minutes (median, 61 minutes; range, 27-113 minutes), and aortic crossclamp duration (when present) was $51 \pm 20$ minutes (median, 51 minutes; range, 23-93 minutes). Three cases did not use cardioplegia, 2 cases used cold blood cardioplegia at $10^{\circ} \mathrm{C}$, and 14 cases used blood cardioplegia at warmer temperatures. Of note, no patient underwent circulatory arrest. The lowest intraoperative nasal or bladder temperatures decreased to less than $35^{\circ} \mathrm{C}$ in 3 cases and to less than $34^{\circ} \mathrm{C}$ in 1 case. Of note, 3 patients (patients 5, 9, and 13) had the CA identified in the operating room. For patients 5 and 9, the perfusionist noted agglutination of blood in cardioplegia heat exchanger with subsequent laboratory studies in both cases confirming the presence of CA. Patient 13 had a routine type and screen drawn the morning of surgery and was then anesthetized for cardiac surgery. Before skin incision, the blood bank reported that a strong reacting antibody was present and that the antibody screen was unable to be completed that day. Surgery was postponed, and the hematology team was consulted. A cold autoantibody was identified, and additional laboratory studies demonstrated no evidence of hemolysis. Surgery was performed using warm blood cardioplegia and avoidance of hypothermia.

Postoperative events, including vasoactive medications and IABP requirements, transfusions, hospital length of stay, and 30-day mortality, are shown in Appendix Table 3. Two patients required an IABP. Ten patients required inotropic support with epinephrine, dopamine, or milrinone. No patient required dialysis postoperatively. There were no reported transfusion-related complications noted in the postoperative period. No patient had a neurologic event. In no patient was additional therapy (other than transfusion) required for treatment of CA or CHAD. After the initial aortic valve replacement, patient 2 experienced hemolysis on postoperative days 3 to 5 , during which time the hematology consultation service was actively involved, the patient was transfused, and active warming of the patient was used. Polyspecific direct antiglobulin tests were performed on postoperative days 2,4 , and 5 , and they were weakly positive, $2+$, and $1+$, respectively. Antibody testing was again performed, revealing only cold autoantibodies. Plasma exchange was considered, but the hemolysis resolved without further treatment.

\section{DISCUSSION}

The key finding in this study is that patients from the Mayo Clinic College of Medicine with benign CA or CA causing CHAD underwent cardiac surgery safely with $\mathrm{CPB}$ and experienced relatively unremarkable postoperative courses, with the exception of 1 case of postoperative hemolysis. When cardioplegia was used, solely anterograde or anterograde in conjunction with retrograde blood cardioplegia was used. For patients with known CA or CHAD preoperatively, cold $\left(10^{\circ} \mathrm{C}\right)$ blood cardioplegia was used intentionally in only 1 case of benign CA with low antibody titers. In addition, in the 4 procedures in which patients received doses of cardioplegia that were $30^{\circ} \mathrm{C}$ or less, there were no adverse outcomes. In all cases of known $\mathrm{CA}$ or CHAD, efforts were made to maintain normothermia of $37^{\circ} \mathrm{C}$ intraoperatively.

Laboratory testing relevant to CHAD includes those related to hemolysis (hemoglobin, direct antiglobulin test, lactate dehydrogenase, haptoglobin, free plasma hemoglobin, and bilirubin) and others related to the quantification and activity of CA antibodies (CA antibody titer and thermal amplitude, respectively). ${ }^{3,9,11}$ The method of CA titer quantification at the Mayo Clinic College of Medicine is detailed in Appendix 4. There is potential for inaccuracy and significant interoperator variability in performing antibody titers because of the subjective nature of the end point of the reaction. ${ }^{8}$ There is no consensus on the CA antibody titer that is clinically significant and warrants appropriate precautions. Although titers greater than 64 are considered elevated, CHAD and hemolysis at the temperature reached in the peripheral circulation rarely occur unless titers are greater than $1000 .{ }^{13}$ Previous reports of patients with CA undergoing $\mathrm{CPB}$ have cited a titer range from greater than 32 to greater than 1000 as clinically significant. ${ }^{12,14,15}$ Thermal amplitude correlates antibody activity to temperature and is commonly reported by measuring the highest temperature at which agglutination is observed in vitro. Increasing thermal amplitude signifies autoantibody activity at warmer temperatures and thus more readily facilitates complement fixation potentially resulting in red blood cells hemolysis. ${ }^{3,8,9}$ Thermal amplitude determination may be beneficial to determine whether systemic hypothermia or cold cardioplegia administration will be tolerated if there is a strong surgical indication for either. As previously indicated, all patients will have naturally occurring cold agglutination when the temperature is decreased to levels that are rarely clinically relevant $\left(\mathrm{eg}, 4^{\circ} \mathrm{C}\right) .{ }^{1} \mathrm{Clinical}$ severity of CHAD is more closely related to thermal amplitude than antibody titer. ${ }^{16}$ Some have recommended that all patients requiring $\mathrm{CPB}$ undergo rigorous testing for $\mathrm{CA}$, including thermal amplitude, antibody titer, and antigen specificity determination, ${ }^{17,18}$ but others have questioned the utility and feasibility of this recommendation. ${ }^{19,20}$ In Figure 1, we suggest an algorithm to guide preoperative testing in patients with CA and CHAD.

Routine blood antibody screening in the Mayo Clinic College of Medicine's blood bank is performed initially at $24^{\circ} \mathrm{C}$ and then after incubating at $37^{\circ} \mathrm{C}$. Detection of agglutination during immediate spin antibody screening or 
Cardiac surgery requiring $\mathrm{CPB}$ in a patient with $\mathrm{CA}$ or $\mathrm{CHAD}$

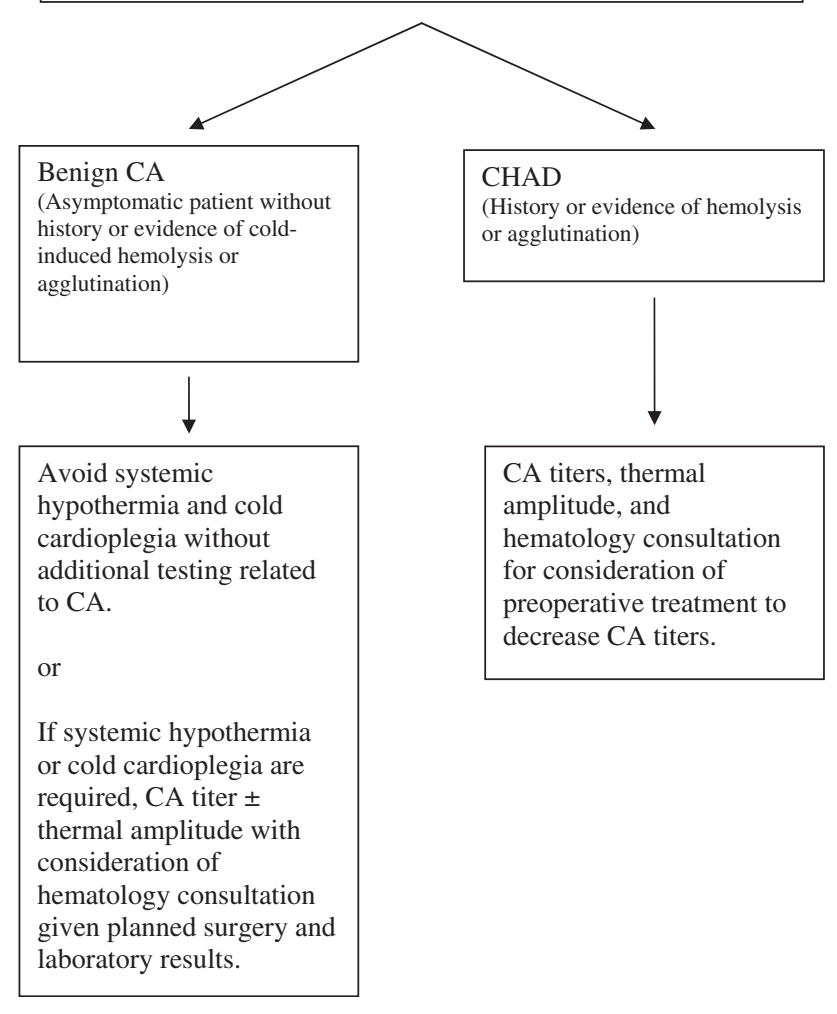

FIGURE 1. Recommendations for preoperative testing and hematology consultation in patients with benign $\mathrm{CA}$ and CHAD. $C P B$, Cardiopulmonary bypass; $C A$, cold agglutinins; $C H A D$, cold hemagglutinin disease.

during $\mathrm{ABO}$ typing, which occurs at room temperature, may represent CA. This was how CA were initially identified in 4 patients $(25 \%)$ in the current study. In these patients, there was no preexisting diagnosis of $\mathrm{CA}$ or CHAD, and none had preoperative symptoms of CHAD. Although only 1 of these patients (patient 13) underwent further CA testing that consisted of CA titer determination, further laboratory testing such as thermal amplitude and CA titers may aid the clinician in management, especially in patients in whom deep hypothermia is considered.

Preoperatively, 6 patients (38\%) in this study had clinical manifestations of CHAD. Medical therapies for patients with CHAD or CA include plasma exchange, rituximab, cyclophosphamide, chlorambucil, glucocorticoids, intravenous immunoglobulin, splenectomy (although rarely effective for CHAD), erythropoietin, and red blood cell transfusions (the latter 2 therapies serve to treat anemia and not CA production). ${ }^{2,4,7,9,10,16,21-23}$ In our series, only 1 patient underwent plasma exchange, 1 patient required preoperative red blood cell transfusion before both surgeries, and 1 patient had undergone splenectomy because of the concomitant presence of warm autoantibodies. Plasma exchange provides a rapid, reliable, and temporary reduction in CA antibody titer and is often used for patients with CHAD but, along with the other treatments mentioned earlier, may not be appropriate or indicated for patients who simply had CA without the presence of hemolysis., ${ }^{2,23}$ Preoperative consultation with physicians from our Department of Hematology was obtained in the majority of patients. The hematologists serve as part of the multidisciplinary team approach to patient care in guiding and interpreting necessary preoperative testing, assisting with preoperative reduction of $\mathrm{CA}$ if necessary, and consulting with the surgeon to delineate risks and benefits of CPB temperature management in relation to an individual's planned operation and CA severity. Although not all hematologists may have an interest in benign hematology including CA, this area should be covered in hematologists' training and they should have the ability to assist in perioperative laboratory testing and management of patients with CA or CHAD. Otherwise, referral should be made to a hematologist or tertiary care center equipped to assist in the perioperative management.

Of particular challenge is the patient with CA that is discovered intraoperatively. In the present study, the presence of CA was diagnosed intraoperatively in 3 patients $(19 \%)$. Because these patients did not demonstrate signs or symptoms of CHAD, these antibodies seemed to be the benign cold autoantibodies that represent a variant of normal. In 1 patient, CPB had been instituted, cold anterograde cardioplegia was administered, and agglutination was noted in the cardioplegia heat exchanger. Warm blood cardioplegia was immediately administered, and the patient was kept normothermic on CPB. A second patient was noted to have agglutination in the CPB circuit before institution of CPB. Anterograde warm blood cardioplegia and normothermic CPB were used. In a third patient, surgery was postponed to allow further workup when the preoperative type and screen revealed a strongly active antibody.

Previous reports have described management of patients in whom the diagnosis of CA disease was made intraoperatively, as shown in Table $1 .^{12,17-19}$ These strategies serve to mitigate further agglutination in the coronary circulation and the potential for myocardial damage by avoiding further cardioplegia, returning the patient to normothermia, attempting to wash microemboli from the coronary circulation, or changing from blood to crystalloid cardioplegia. However, crystalloid cardioplegia may provide inferior myocardial protection when compared with blood cardioplegia. $^{24}$

Intraoperative management of patients with $\mathrm{CA}$ and CHAD can be divided into 2 major areas: measures unrelated to CPB to avoid sequelae of CA disease and management strategies pertaining to $\mathrm{CPB}$ and cardioplegia. Our practice has been strict avoidance of hypothermia whenever feasible with use of forced-air warming devices and warmed intravenous fluids, as other authors have recommended..$^{20,21}$ The lowest intraoperative temperatures recorded in our series were higher than those reported in a previous series 
TABLE 1. Cardiopulmonary bypass and cardioplegia management strategies for cold agglutinins

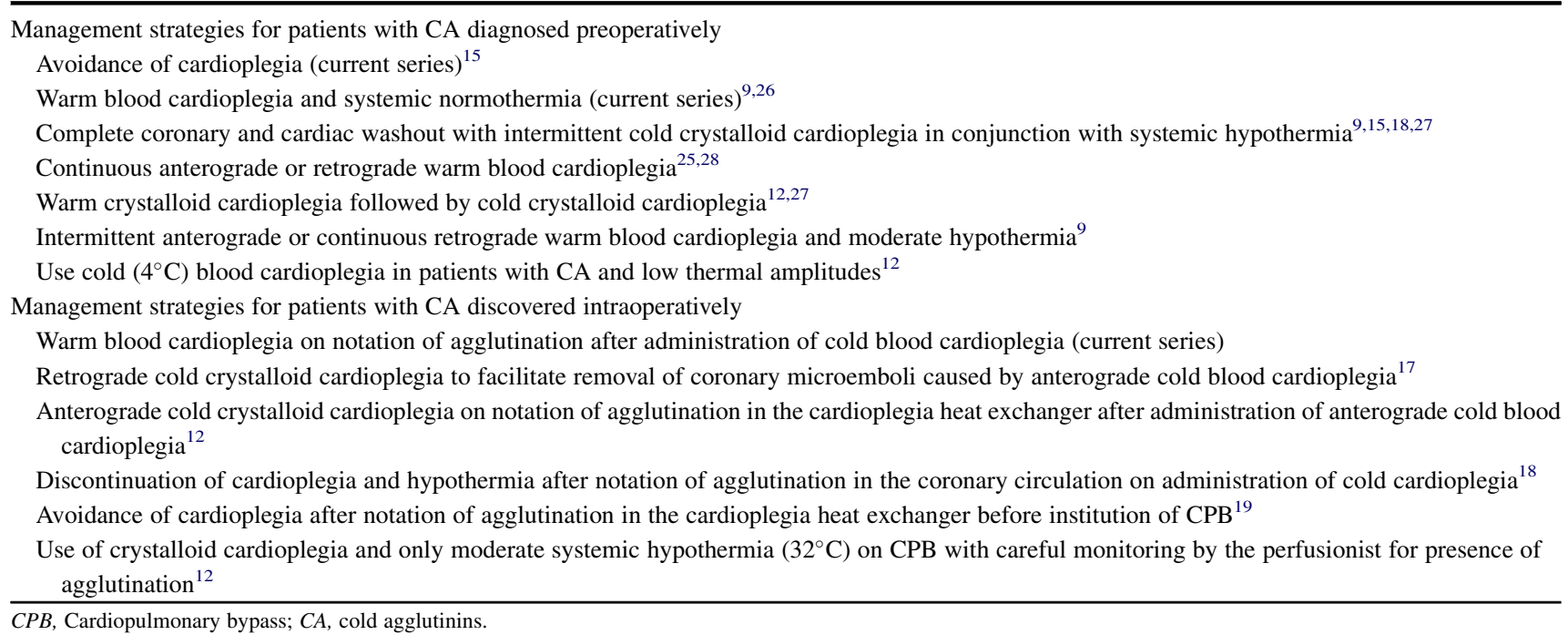

of 20 patients. ${ }^{12}$ In relation to $\mathrm{CPB}$, previous reports have described multiple different techniques to successfully manage patients with CA intraoperatively, as shown in Table $1.9,12,15,18,25-28$ One study specifically noted no difference in hemolysis during CPB between patients with and without $\mathrm{CA} .{ }^{29}$ Other authors have reported that cold blood cardioplegia can be safely used in patients with CA even if visible intracoronary agglutination is noted, but this stance is controversial. ${ }^{30}$ Successful off-pump coronary artery bypass has been reported in a patient with CHAD. ${ }^{31}$ In our practice, we avoid systemic hypothermia by using normothermic $\mathrm{CPB}$ at $37^{\circ} \mathrm{C}$ with no cardioplegia when cardiac arrest can be avoided or intermittent anterograde warm blood cardioplegia at $37^{\circ} \mathrm{C}$ (occasionally in conjunction with continuous retrograde warm blood cardioplegia). The small sample size of our series and the limited number of other small series and case reports make it difficult to draw definitive conclusions regarding the most suitable CPB and cardioplegia technique. As with the majority of patients in our series lacking CA laboratory testing to define thermal spectrum of activity, using CPB and cardioplegia techniques that avoid risk of agglutination and hemolysis in the coronary and systemic circulations seems to be a safe and generally acceptable practice. In asymptomatic patients with low CA antibody titers, it has been suggested that hypothermic CPB may be safely performed, as was observed with patient 16 in our series. ${ }^{14}$

Although no patients in our series required deep hypothermic circulatory arrest, case reports of patients with $\mathrm{CA}^{32}$ and $\mathrm{CHAD}^{22}$ successfully undergoing deep hypothermia above the thermal amplitude exist. In these cases, the thermal amplitude was used to guide a safe level of hypothermia.

No patient in the present series died within 30 days of surgery. Case reports of death within 30 days of cardiac surgery requiring $\mathrm{CPB}$ exist, but the cause was not directly attributed to $\mathrm{CA} .{ }^{12}$ All but 5 procedures in our series required postoperative red blood cell transfusions. In only 1 patient (patient 2) was treatment considered for CHAD due to ongoing postoperative hemolysis. In this case, plasma exchange was considered; however, the hemolysis resolved after conservative management consisting of actively warming the patient. Prolonged postoperative hemolysis has been reported in a patient with CA undergoing cardiac surgery with hypothermia. ${ }^{11}$ This is a rare complication that we did not note in our practice and has not been shown in other series. $9,12,14$ In the 11 patients requiring postoperative vasoactive medications, the requirements were consistent with preoperative myocardial function and type of operation. In none of these patients was the vasoactive requirement unexpected such that we would have been concerned about CA-induced myocardial ischemia.

\section{Study Limitations}

This study has all the inherent limitations of a retrospective case series, including uncertainty of reasons for management decisions and charting omissions. By definition, only patients undergoing cardiac surgery requiring CPB were included. Therefore, patients undergoing off-pump cardiac surgery were not included. Cases of patients with CA undergoing CPB may have been missed if they were undiagnosed perioperatively or excluded because they were aged less than 16 years, because CA occur in childhood as well. Patients' blood was likely exposed to temperatures lower than the minimum measured temperatures reported in Appendix Table 2 because of the CPB circuit temperature being less than the patients' nadir temperatures. In addition, it is important to note that blood cardioplegia is diluted with crystalloid, resulting in reduced CA levels in the cardioplegia that may decrease the incidence of intraoperative 
complications from cold cardioplegia administration. An increasing trend of normothermic $\mathrm{CPB}$ in recent years may have reduced the number of $\mathrm{CA}$ discovered intraoperatively and the perioperative complications related to CA. Finally, no patients with CA or CHAD underwent deep hypothermic circulatory arrest in this study.

\section{CONCLUSIONS}

CHAD is a rare condition, and benign CA, although a variant of normal, rarely are detectable on routine screening and therefore is also uncommon in patients undergoing CPB. As outlined in Figure 1, patients with benign CA (but without evidence of CHAD) who can safely undergo cardiac surgery with normothermia and warm cardioplegia at $37^{\circ} \mathrm{C}$ do not require additional testing. If systemic hypothermia or cold cardioplegia is required, the following are recommended for patients with benign CA: CA titers, thermal amplitude, and hematology consultation to assist with perioperative CA management, if necessary, given laboratory results and planned surgery. Although not recommended for all patients with benign $\mathrm{CA}$, the most conservative preoperative laboratory testing on a case-by-case basis would include CA titers and thermal amplitudes, in the unlikely event of an unanticipated intraoperative emergency requiring hypothermia or circulatory arrest. Patients with CHAD require preoperative laboratory testing and hematology consultation for consideration of appropriate preoperative CA management. Finally, we are unable to make recommendations regarding the management of pediatric patients with benign CA or CHAD undergoing cardiac surgery, because this patient population was excluded from the current study.

\section{References}

1. Issitt PD, Anstee DJ. Cold hemagglutinin disease and paroxysmal cold hemoglobinuria. In: Applied Blood Group Serology. 4th ed. Durham, NC: Montgomery Scientific Publications; 1998:995-1008.

2. Gertz MA. Cold agglutinin disease and cryoglobulinemia. Clin Lymphoma. 2005;5:290-3.

3. Wintrobe MM, Greer JP. Wintrobe's Clinical Hematology. 12th ed. Philadelphia: Wolters Kluwer Health/Lippincott Williams \& Wilkins; 2009.

4. Berentsen S, Ulvestad E, Langholm R, Beiske K, Hjorth-Hansen H, Ghanima W, et al. Primary chronic cold agglutinin disease: a population based clinical study of 86 patients. Haematologica. 2006;91:460-6.

5. Hadnagy C. Agewise distribution of idiopathic cold agglutinin disease. Z Gerontol. 1993;26:199-201.

6. Ulvestad E. Paradoxical haemolysis in a patient with cold agglutinin disease. Eur J Haematol. 1998;60:93-100.

7. Gertz MA. Management of cold haemolytic syndrome. Br J Haematol. 2007; $138: 422-9$
8. Rosse WF, Adams JP. The variability of hemolysis in the cold agglutinin syndrome. Blood. 1980;56:409-16.

9. Agarwal SK, Ghosh PK, Gupta D. Cardiac surgery and cold-reactive proteins. Ann Thorac Surg. 1995;60:1143-50.

10. Park JV, Weiss CI. Cardiopulmonary bypass and myocardial protection: management problems in cardiac surgical patients with cold autoimmune disease. Anesth Analg. 1988;67:75-8

11. Wertlake PT, McGinniss MH, Schmidt PJ. Cold antibody and persistent intravascular hemolysis after surgery under hypothermia. Transfusion. 1969;9:70-3.

12. Bracken CA, Gurkowski MA, Naples JJ, Smith H, Steinmann A, Samuel J, et al Case 6-1993. Cardiopulmonary bypass in two patients with previously undetected cold agglutinins. J Cardiothorac Vasc Anesth. 1993;7:743-9.

13. Robak JD, Grossman BJ, Harris T, Hillyer CD, eds. Methods section 3. Antibody detection, identification, and compatibility testing. In: Technical Manual. Bethesda, MD: AABB; 2011:923.

14. Moore RA, Geller EA, Mathews ES, Botros SB, Jose AB, Clark DL. The effect of hypothermic cardiopulmonary bypass on patients with low-titer, nonspecific cold agglutinins. Ann Thorac Surg. 1984;37:233-8.

15. Williams AC. Cold agglutinins. Cause for concern? Anaesthesia. 1980;35:887-9

16. Crisp D, Pruzanski W. B-cell neoplasms with homogeneous cold-reacting antibodies (cold agglutinins). Am J Med. 1982;72:915-22.

17. Izzat MB, Rajesh PB, Smith GH. Use of retrograde cold crystalloid cardioplegia in a patient with unexpected cold agglutination. Ann Thorac Surg. 1993;56: 1395-7.

18. Diaz JH, Cooper ES, Ochsner JL. Cardiac surgery in patients with cold autoimmune diseases. Anesth Analg. 1984;63:349-52.

19. Dake SB, Johnston MF, Brueggeman P, Barner HB. Detection of cold hemagglutination in a blood cardioplegia unit before systemic cooling of a patient with unsuspected cold agglutinin disease. Ann Thorac Surg. 1989;47:914-5.

20. Bedrosian CL, Simel DL. Cold hemagglutinin disease in the operating room. South Med J. 1987;80:466-71.

21. Beebe DS, Bergen L, Palahniuk RJ. Anesthetic management of a patient with severe cold agglutinin hemolytic anemia utilizing forced air warming. Anesth Analg. 1993;76:1144-6.

22. Pecsi SA, Almassi GH, Langenstroer P. Deep hypothermic circulatory arrest for a patient with known cold agglutinins. Ann Thorac Surg. 2009;88:1326-7.

23. Zoppi M, Oppliger R, Althaus U, Nydegger U. Reduction of plasma cold agglutinin titers by means of plasmapheresis to prepare a patient for coronary bypass surgery. Infusionsther Transfusionsmed. 1993;20:19-22.

24. Guru V, Omura J, Alghamdi AA, Weisel R, Fremes SE. Is blood superior to crystalloid cardioplegia? A meta-analysis of randomized clinical trials. Circulation 2006;114(1 Suppl):I331-8.

25. Gokhale AG, Suhasini T, Saraswati V, Chandrasekhar N, Rajagopal P. Cold agglutinins and warm heart surgery. J Thorac Cardiovasc Surg. 1993;105:557.

26. Mastrogiovanni G, Masiello P, Iesu S, Senese I, Di Benedetto G. Management of cold agglutinemia with intermittent warm blood cardioplegia and normothermia. Ann Thorac Surg. 1996;62:317.

27. Shahian DM, Wallach SR, Bern MM. Open heart surgery in patients with coldreactive proteins. Surg Clin North Am. 1985;65:315-22.

28. Aoki A, Kay GL, Zubiate P, Ruggio J, Kay JH. Cardiac operation without hypothermia for the patient with cold agglutinin. Chest. 1993;104:1627-9.

29. AuBuchon JP, Scofan BA, Davey RJ. Hemolysis during extracorporeal circulation. Significance of cold-reactive auto-antibodies and mechanical trauma. Blood. 1983;65:42a.

30. Holman WL, Smith SH, Edwards R, Huang ST. Agglutination of blood cardioplegia by cold-reacting autoantibodies. Ann Thorac Surg. 1991;51:833-6.

31. Bratkovic K, Fahy C. Anesthesia for off-pump coronary artery surgery in a patient with cold agglutinin disease. J Cardiothorac Vasc Anesth. 2008;22:449-52.

32. Leach AB, Van Hasselt GL, Edwards JC. Cold agglutinins and deep hypothermia. Anaesthesia. 1983;38:140-3. 
APPENDIX TABLE 1. Preoperative characteristics and findings of patients with cold agglutinins undergoing surgery requiring cardiopulmonary bypass

\begin{tabular}{|c|c|c|c|c|c|c|c|c|}
\hline $\begin{array}{c}\text { Patient } \\
\text { no. }\end{array}$ & $\begin{array}{c}\text { Age at } \\
\text { surgery }(y) / g e n d e r\end{array}$ & $\begin{array}{l}\text { CA or } \\
\text { CHAD }\end{array}$ & How diagnosed & Time of diagnosis & Cause & $\begin{array}{l}\text { Symptoms } \\
\text { of CHD } \\
\text { documented }\end{array}$ & $\begin{array}{l}\text { CA titer } \\
\text { at } 4^{\circ} \mathrm{C}^{*}\end{array}$ & Thermal amplitude $\left({ }^{\circ} \mathrm{C}\right)$ \\
\hline 1 & $16 \mathrm{~F}$ & CHAD & Anemia workup & Preoperatively & Unknown & Yes & 256 & NP \\
\hline 2 & $74 \mathrm{~F}$ & CHAD & Preexisting diagnosis $\ddagger$ & Preoperatively & $\begin{array}{l}\text { Lymphoproliferative } \\
\text { disorder }\end{array}$ & Yes & 8192 & $3+$ at $30^{\circ} \mathrm{C}, 4+$ at $26^{\circ} \mathrm{C}$ \\
\hline 2 & $77 \mathrm{~F}$ & CHAD & Preexisting diagnosis & Preoperatively & $\begin{array}{l}\text { Lymphoproliferative } \\
\text { disorder }\end{array}$ & Yes & $>512$ & $3+$ at $30^{\circ} \mathrm{C}, 4+$ at $26^{\circ} \mathrm{C}$ \\
\hline 3 & $68 \mathrm{~F}$ & $\mathrm{CA}$ & Preexisting diagnosis & Preoperatively & Postinfectious & No & 128 & $\begin{array}{l}\mathrm{w}+\text { to } 1+\text { at } 30^{\circ} \mathrm{C}, 2+\text { to } 3+\text { at } \\
22^{\circ} \mathrm{C} \text {, no reaction at } 37^{\circ} \mathrm{C}\end{array}$ \\
\hline 4 & $76 \mathrm{M}$ & CHAD & Preexisting diagnosis & Preoperatively & Unknown & Yes & 131,072 & NP \\
\hline 5 & $73 \mathrm{M}$ & $\mathrm{CA}$ & Agglutination on $\mathrm{CPB}$ & Intraoperatively & Postinfectious & No & NP & NP \\
\hline 6 & $81 \mathrm{~F}$ & CHAD & Preexisting diagnosis & Preoperatively & Unknown & Yes & $64-512$ & NP \\
\hline 7 & $80 \mathrm{M}$ & CHAD & Preexisting diagnosis & Preoperatively & Unknown & Yes & $>512$ & $\begin{array}{c}\text { Negative at } 37, \text { negative at } 30, \\
\text { and } w+\text { at } 22 \text { per outside } \\
\text { hospital }\end{array}$ \\
\hline 8 & $69 \mathrm{~F}$ & CHAD & Preexisting diagnosis & Preoperatively & Unknown & Yes & $160 \S$ & $\mathrm{NP}$ \\
\hline 9 & $42 \mathrm{M}$ & CA & $\begin{array}{l}\text { Agglutination in } \mathrm{CPB} \\
\text { circuit before } \\
\text { institution of } \mathrm{CPB}\end{array}$ & Intraoperatively & Unknown & No & $\mathrm{NP}$ & NP \\
\hline 10 & $66 \mathrm{M}$ & $\mathrm{CA}$ & $\begin{array}{l}\text { Blood type and screen } \\
\text { day of surgery }\end{array}$ & Preoperatively & $\begin{array}{l}\text { Lymphoproliferative } \\
\text { disorder }\end{array}$ & No & NP & NP \\
\hline 11 & $74 \mathrm{~F}$ & CA & Preexisting diagnosis & Preoperatively & Unknown & No & $<64$ & $22^{\circ} \mathrm{C}$ per outside hospital \\
\hline 12 & $67 \mathrm{M}$ & $\mathrm{CA}$ & $\begin{array}{l}\text { Preoperative blood type } \\
\text { and screen }\end{array}$ & Preoperatively & Unknown & No & NP & NP \\
\hline 13 & $76 \mathrm{M}$ & $\mathrm{CA}$ & $\begin{array}{l}\text { Preoperative blood type } \\
\text { and screen }\end{array}$ & Intraoperatively\| & Unknown & No & $>512$ & NP \\
\hline 13 & $76 \mathrm{M}$ & $\mathrm{CA}$ & $\begin{array}{l}\text { Preoperative blood type } \\
\text { and screen }\end{array}$ & Intraoperatively\| & Unknown & No & $>512$ & NP \\
\hline 14 & $80 \mathrm{M}$ & $\mathrm{CA}$ & Anemia workup & Preoperatively & Unknown & Yes & 8 & NP \\
\hline 15 & $71 \mathrm{M}$ & $\mathrm{CA}$ & $\begin{array}{l}\text { Preoperative blood type } \\
\text { and screen }\end{array}$ & Preoperatively & Unknown & No & NP & NP \\
\hline 16 & $68 \mathrm{~F}$ & $\mathrm{CA}$ & Anemia workup & Preoperatively & Unknown & No & 2 & NP \\
\hline 16 & $69 \mathrm{~F}$ & $\mathrm{CA}$ & Anemia workup & Preoperatively & Unknown & No & 2 & NP \\
\hline
\end{tabular}

All laboratory testing was performed at Mayo Clinic unless indicated otherwise. $C A$, Cold agglutinins; $C H A D$, cold hemagglutinin disease; $C P B$, cardiopulmonary bypass; $C H D$, congestive heart disease; $D A T$, direct antiglobulin test; $N P$, not performed; $E F$, ejection fraction; $H b$, hemoglobin; $C r$, creatinine; $L D H$, lactate dehydrogenase; anti- $G$, antiimmunoglobulin-G direct antiglobulin test; anti-C, anti-complement direct antiglobulin test; $m+$, microscopic positive only; poly, polyspecific direct antiglobulin test; $w+$, weak positive. *The manner in which titers are quantified at Mayo Clinic was changed during this retrospective study. Before the change, titers were reported as exact titer values, and subsequently they are reported as ranges with an upper level of $>512$. $\dagger$ A polyspecific direct antiglobulin test detects the presence of immunoglobulin-G or complement. Specific direct antiglobulin test consists of anti-immunoglobulin-G and anti-complement testing. Test results are graded on a scale of increasing positivity as negative, microscopic positive, weak positive, $1+, 2+, 3+$, and $4+$. †Preexisting diagnosis signifies patient presented to Mayo Clinic with the diagnosis of CA or CHAD from the referring institution. $\S$ This CA titer was reported from an outside institution. \|Two days before the patient underwent CPB, a routine type and antibody screen were drawn. He was then anesthetized, and venous and arterial access was secured. The blood bank notified the operating room staff that because of a strong reacting antibody, the antibody screen was unable to be completed that day. Surgery was postponed, and the patient was awakened and taken to the cardiac surgical unit to await the results of the antibody screen and have a hematology consult. A cold autoantibody was identified, and additional laboratory studies demonstrated no evidence of hemolysis. Hematology recommended proceeding with surgery and using only warm cardioplegia while avoiding hypothermia. $\{$ Despite the presence of autoimmune hemolytic anemia in this patient with both CA and warm autoantibodies, the laboratory results were consistent with warm autoantibodies causing hemolysis and not CHAD. 
APPENDIX TABLE 1. Continued

\begin{tabular}{|c|c|c|c|c|c|c|c|c|}
\hline $\mathbf{D A T} \dagger$ & $\begin{array}{c}\text { Valvular pathology } \\
\text { contributing to hemolysis } \\
\end{array}$ & $\begin{array}{l}\mathbf{E F} \\
(\%) \\
\end{array}$ & $\begin{array}{c}\mathbf{H b} \\
(\mathrm{g} / \mathrm{dL})\end{array}$ & $\begin{array}{c}\mathbf{C r} \\
(\mathbf{m g} / \mathbf{d L})\end{array}$ & $\begin{array}{l}\text { Bilirubin total/ } \\
\text { direct (mg/dL) }\end{array}$ & $\begin{array}{c}\text { LDH (U/L) } \\
\text { (normal, 122-222) } \\
\end{array}$ & $\begin{array}{c}\text { Haptoglobin (mg/dL) } \\
\text { (normal, 30-200) }\end{array}$ & $\begin{array}{c}\text { Hematology } \\
\text { consult before } \\
\text { surgery } \\
\end{array}$ \\
\hline Poly negative & No & 64 & 10.4 & 0.9 & $1.2 / 0.3$ & $\begin{array}{c}234 \text { (pediatric reference range, } \\
105-233 \text { ) }\end{array}$ & 31 & Yes \\
\hline $\begin{array}{l}\text { Poly } 2+ \\
\text { Anti-G m+ } \\
\text { Anti-C } 2+\end{array}$ & No & 64 & 6.8 & 0.7 & $4.1 / 0.3$ & 381 & NP & Yes \\
\hline $\begin{array}{l}\text { Poly } 1+ \\
\text { Anti-G negative } \\
\text { Anti-C } 1+\end{array}$ & Yes & 37.5 & 9.4 & 0.6 & $6.1 / 1.2$ & 904 & $<14$ & Yes \\
\hline $\begin{array}{l}\text { Poly } 1+ \\
\text { Anti-G negative } \\
\text { Anti-C } 1+\end{array}$ & No & 52.5 & 11.3 & 1.9 & $0.6 / 0.2$ & 217 & NP & Yes \\
\hline $\begin{array}{l}\text { Poly } 1+ \\
\text { Anti-G w+ } \\
\text { Anti-C w+ }\end{array}$ & No & 70 & 12.1 & 0.9 & NP & 252 & NP & Yes \\
\hline NP & No & 60 & 13.1 & 0.9 & NP & $\mathrm{NP}$ & NP & No \\
\hline $\begin{array}{l}\text { Poly w+ } \\
\text { Anti-G NP } \\
\text { Anti-C NP }\end{array}$ & No & 70 & 11.9 & 1 & Total 1 & 517 & 157 & Yes \\
\hline $\begin{array}{l}\text { Poly } 1+ \\
\text { Anti-G negative } \\
\text { Anti-C w }+\end{array}$ & No & 23 & 13 & 1.4 & $1.7 / 0.6$ & 268 & NP & Yes \\
\hline $\mathrm{NP}$ & No & 66 & 15 & 0.8 & $0.9 / 0.3$ & NP & NP & Yes \\
\hline $\begin{array}{l}\text { Poly } w+ \\
\text { Anti-G negative } \\
\text { Anti-C w }+\end{array}$ & No & 63 & 14.8 & 0.9 & $1 / 0.3$ & NP & NP & No \\
\hline NP & No & 58 & 14 & 1 & $0.7 / 0.2$ & 176 & NP & No \\
\hline NP & No & 60 & 11.9 & 1 & NP & NP & NP & Yes \\
\hline NP & No & 43 & 13.2 & 1.2 & $0.6 / 0.2$ & NP & NP & No \\
\hline NP & No & 68 & 11.8 & 0.8 & Direct 0.2 & 130 & 94 & Yes \\
\hline NP & No & 68 & 11.8 & 0.8 & Direct 0.2 & 130 & 94 & Yes \\
\hline $\begin{array}{l}\text { Poly } 1+ \\
\text { Anti-G } 1+ \\
\text { Anti-C negative }\end{array}$ & No & 62 & 10.5 & 1.4 & $0.5 / .1$ & 210 & 72 & Yes \\
\hline $\begin{array}{l}\text { Poly } w+ \\
\text { Anti-G negative } \\
\text { Anti-C w }+\end{array}$ & No & 73 & 13.6 & 1.1 & $\mathrm{NP}$ & NP & NP & No \\
\hline $\begin{array}{l}\text { Poly negative } \\
\text { Anti-G NP } \\
\text { Anti-C NP }\end{array}$ & Yes & 49 & 10.9 & 1.3 & $2.6 / 0.6$ & $\mathrm{NP}$ & $<14$ & Yes \\
\hline $\begin{array}{l}\text { Poly negative } \\
\text { Anti-G NP } \\
\text { Anti-C NP }\end{array}$ & Yes & 42.5 & 10.2 & 0.9 & $\mathrm{NP}$ & $\mathrm{NP}$ & $<14$ & Yes \\
\hline
\end{tabular}


APPENDIX TABLE 2. Intraoperative findings and management of patients with cold agglutinins undergoing surgery requiring cardiopulmonary bypass

\begin{tabular}{|c|c|c|c|c|c|c|c|}
\hline $\begin{array}{c}\text { Patient } \\
\text { no. }\end{array}$ & Procedure(s) & $\begin{array}{c}\text { Anesthesia } \\
\text { duration (min) }\end{array}$ & Warming methods used & CP route & $\begin{array}{l}\text { CP temperature } \\
\text { and composition }\end{array}$ & $\begin{array}{l}\text { Continuous } \\
\text { retrograde } \\
\text { CP }\end{array}$ & $\begin{array}{c}\text { CP } \\
\text { intervals } \\
(\text { min) }\end{array}$ \\
\hline 1 & $\begin{array}{l}\text { Tricuspid valve re-replacement } \\
\text { (mechanical) }\end{array}$ & 364 & Not specified & None & NA & No & NA \\
\hline 2 & $\begin{array}{l}\text { Aortic valve replacement } \\
\text { (bioprosthetic) }\end{array}$ & 172 & $\begin{array}{l}\text { Two FAW, IVFW, OR kept } \\
\text { warm }\end{array}$ & Anterograde & Warm* blood & No & 15 \\
\hline 2 & $\begin{array}{l}\text { Aortic valve re-replacement } \\
\quad \text { (mechanical) }\end{array}$ & 236 & $\begin{array}{l}\text { FAW, IVFW, OR kept at } 80^{\circ} \mathrm{F}, \\
\text { blood samples kept warm on } \\
\text { transport to laboratory }\end{array}$ & Anterograde & Warm blood & No & 20 \\
\hline 3 & $\begin{array}{l}\text { Aortic valve replacement } \\
\text { (bioprosthetic), foramen } \\
\text { ovale closure }\end{array}$ & 303 & FAW, IVFW & $\begin{array}{l}\text { Anterograde } \\
\text { and retrograde }\end{array}$ & Warm blood & Yes & $15-20$ \\
\hline 4 & $\begin{array}{l}\text { Aortic valve replacement } \\
\text { (bioprosthetic) }\end{array}$ & 198 & $\begin{array}{l}\text { FAW, IVFW for all venous } \\
\text { lines, OR kept at } 75^{\circ} \mathrm{F}\end{array}$ & Anterograde & Warm blood & No & NA \\
\hline 5 & $\begin{array}{l}\text { Aortic valve replacement } \\
\quad \text { (bioprosthetic) }\end{array}$ & 217 & FAW, IVFW & Anterograde & $\begin{array}{l}\text { Cold }\left(10^{\circ} \mathrm{C}\right) \text { blood } \\
\text { followed by warm } \\
\text { blood on discovery } \\
\text { of agglutination } \dagger\end{array}$ & No & 20 \\
\hline 6 & $\begin{array}{r}\text { Aortic valve replacement } \\
\text { (bioprosthetic), CABG }\end{array}$ & 355 & FAW, IVFW & Anterograde & Warm blood $\ddagger$ & No & $5-10$ \\
\hline 7 & $\begin{array}{l}\text { Aortic valve replacement } \\
\quad \text { (bioprosthetic), CABG } \times 1\end{array}$ & 359 & $\begin{array}{l}\text { FAW, multiple IVFW, OR kept } \\
\text { at } 78^{\circ} \mathrm{F}\end{array}$ & Anterograde & Warm blood & No & 10 \\
\hline 8 & Tricuspid valve repair & 221 & FAW, IVFW & None & NA & No & NA \\
\hline 9 & Mitral valve repair & 222 & FAW, IVFW & Anterograde & Warm blood & No & $15-20$ \\
\hline 10 & CABG & 541 & FAW, IVFW for all venous lines & $\begin{array}{l}\text { Anterograde } \\
\text { and retrograde }\end{array}$ & Warm blood & No & 20 \\
\hline 11 & $\begin{array}{l}\text { Mitral valve re-replacement } \\
\text { (mechanical), tricuspid valve } \\
\text { repair }\end{array}$ & 476 & FAW, IVFW & $\begin{array}{l}\text { Anterograde } \\
\text { and retrograde }\end{array}$ & $28^{\circ} \mathrm{C}$ blood & Yes & $20-25$ \\
\hline 12 & CABG & 301 & FAW, IVFW & $\begin{array}{l}\text { Anterograde and } \\
\text { via vein graft }\end{array}$ & $30^{\circ} \mathrm{C}-34^{\circ} \mathrm{C}$ blood $\ddagger$ & No & $15-20$ \\
\hline $13 \S$ & $\begin{array}{l}\text { Aortic valve replacement } \\
\text { (bioprosthetic) }\end{array}$ & 424 & FAW, IVFW, OR kept warm & Anterograde & Warm blood & No & 15 \\
\hline $13 \S$ & Ascending aorta repair & See above row & FAW, IVFW, OR kept warm & None & NA & No & NA \\
\hline 14 & $\begin{array}{l}\text { Aortic valve replacement } \\
\text { (bioprosthetic) }\end{array}$ & 345 & FAW, IVFW & Anterograde & Warm blood & No & 20 \\
\hline 15 & $\begin{array}{l}\text { Aortic valve replacement } \\
\text { (bioprosthesis, CABG) }\end{array}$ & 271 & FAW, IVFW & Anterograde & Warm blood & No & 20 \\
\hline $16 \|$ & $\begin{array}{r}\mathrm{CABG} \text {, mechanical mitral } \\
\text { perivalvular leak repair }\end{array}$ & 411 & FAW, IVFW & Anterograde & Warm blood & No & 20 \\
\hline 16 & $\begin{array}{l}\text { Mechanical mitral perivalvular } \\
\text { leak re-repair, tricuspid valve } \\
\text { annuloplasty }\end{array}$ & 260 & FAW, IVFW & Anterograde & Cold blood $\left(10^{\circ} \mathrm{C}\right)$ & No & 20 \\
\hline
\end{tabular}

$C P$, Cardioplegia; $C P B$, cardiopulmonary bypass; $R B C$, red blood cell; $F F P$, fresh-frozen plasma; $C A B G$, coronary artery bypass grafting; $F A W$, forced-air warmer; $I V F W$, intravenous fluid warmer; $O R$, operating room; $N A$, not applicable; $T A$, tranexamic acid; $A C A$, aminocaproic acid. * Warm blood cardioplegia indicates a temperature of $35^{\circ} \mathrm{C}$ to $37^{\circ} \mathrm{C}$. †Perfusionist noted agglutination of blood in cardioplegia heat exchanger. Cold cardioplegia was then discontinued and warm cardioplegia administered. $\ddagger$ Difficulty in arresting the heart was noted by the surgeon in these 2 patients. §This patient required a second CPB run after completion of the aortic valve replacement because of electromechanical dissociation during sternal closure. Cardiac massage was initiated, and intravenous epinephrine was administered. Because of tearing of the aortic suture line, the patient was re-heparinized and CPB reinitiated to facilitate repair of the ascending aorta. Thirty minutes after weaning from the second CPB run, an IABP was placed. Several hours were then spent normalizing coagulation and surgically achieving hemostasis. The duration of anesthesia ( 424 minutes) included both CPB runs. $\|$ Bleeding in the atrioventricular groove was encountered and surgically repaired after aortic crossclamp removal and before discontinuation of CPB. An IABP was placed to reduce left ventricular pressures to preserve the repair. 
APPENDIX TABLE 2. Continued

\begin{tabular}{|c|c|c|c|c|c|c|c|c|c|}
\hline $\begin{array}{c}\text { Total CP } \\
\text { doses }\end{array}$ & $\begin{array}{c}\text { Circulatory } \\
\text { arrest }\end{array}$ & $\begin{array}{c}\mathrm{CPB} / \\
\text { crossclamp } \\
\text { duration (min) }\end{array}$ & $\begin{array}{c}\text { Lowest } \\
\text { nasal/bladder } \\
\text { temperature }\left({ }^{\circ} \mathrm{C}\right) \\
\end{array}$ & $\begin{array}{l}\text { Agglutination } \\
\text { noted in } \\
\text { operating room }\end{array}$ & $\begin{array}{c}\text { Antifibrinolytic } \\
\text { used }\end{array}$ & $\begin{array}{c}\text { RBC } \\
\text { transfusion } \\
\text { (units) } \\
\end{array}$ & $\begin{array}{c}\text { FFP } \\
\text { transfusion } \\
\text { (units) } \\
\end{array}$ & $\begin{array}{c}\text { Platelet } \\
\text { transfusion } \\
\text { (units) } \\
\end{array}$ & $\begin{array}{c}\text { Cryoprecipitate } \\
\text { transfusion } \\
\text { (units) } \\
\end{array}$ \\
\hline NA & No & $58 / 0$ & $35.5 / 35.6$ & No & Aprotinin & 3 & 1 & 0 & 0 \\
\hline 2 & No & $35 / 30$ & $36.2 / 36.2$ & No & None & 4 & 0 & 0 & 0 \\
\hline 2 & No & $45 / 28$ & $36.4 / 36.9$ & No & $\mathrm{TA}$ & 3 & 0 & 0 & 0 \\
\hline 6 & No & $112 / 77$ & $35.8 / 36.1$ & No & TA & 0 & 0 & 0 & 0 \\
\hline 1 & No & $29 / 23$ & $36.2 / 36.3$ & No & None & 1 & 0 & 0 & 0 \\
\hline 2 & No & $68 / 58$ & $33.4 / 34.5$ & Yes $\dagger$ & $\mathrm{TA}$ & 0 & 0 & 0 & 0 \\
\hline 6 & No & $81 / 68$ & $36 / 36.6$ & No & None & 2 & 0 & 0 & 0 \\
\hline 4 & No & $45 / 35$ & $35.9 / 36.9$ & No & $\mathrm{ACA}$ & 0 & 0 & 0 & 0 \\
\hline NA & No & $35 / 0$ & $35.3 / 35.7$ & No & ACA & 1 & 2 & 1 & 0 \\
\hline 3 & No & $58 / 48$ & $35.9 / 36.1$ & Yes & None & 0 & 0 & 0 & 0 \\
\hline 4 & No & $79 / 62$ & $35.6 / 35.9$ & No & None & 4 & 6 & 1 & 0 \\
\hline 3 & No & $113 / 93$ & $35 / 35.5$ & No & None & 3 & 3 & 2 & 0 \\
\hline 5 & No & $86 / 66$ & $35.7 / 36.1$ & No & None & 0 & 2 & 0 & 0 \\
\hline 2 & No & $39 / 30$ & $36.5 / 36.8$ & No & None & 11 & 8 & 4 & 2 \\
\hline NA & No & $27 / 0$ & $36.5 / 36.8$ & No & None & $\begin{array}{l}\text { See above } \\
\text { row }\end{array}$ & $\begin{array}{c}\text { See above } \\
\text { row }\end{array}$ & $\begin{array}{c}\text { See above } \\
\text { row }\end{array}$ & $\begin{array}{l}\text { See above } \\
\text { row }\end{array}$ \\
\hline $\begin{array}{l}\text { Not present } \\
\text { in records }\end{array}$ & No & $61 / 53$ & $34.6 / 35$ & No & $\mathrm{TA}$ & 2 & 0 & 0 & 0 \\
\hline 3 & No & $76 / 63$ & $35.9 / 36.1$ & No & $\mathrm{TA}$ & 0 & 0 & 0 & 0 \\
\hline 2 & No & $75 / 35$ & $34.5 / 35.1$ & No & None & 4 & 2 & 1 & 0 \\
\hline 2 & No & $71 / 40$ & $35 / 35.5$ & No & Aprotinin & 3 & 2 & 0 & 0 \\
\hline
\end{tabular}




\begin{tabular}{|c|c|c|c|c|c|c|}
\hline Patient no. & Preoperative EF (\%) & $\begin{array}{l}\text { IABP or vasopressor with highest dose } \\
\text { (initiation time/length of use) }\end{array}$ & RBC transfusion & Platelet (units) & FFP (units) & $\begin{array}{c}\text { Cryoprecipitat } \\
\text { (units) }\end{array}$ \\
\hline 1 & 64 & $\begin{array}{l}\text { Epinephrine } 0.07 \mu \mathrm{g} / \mathrm{kg} / \mathrm{min}(\mathrm{OR} / 2 \mathrm{~d}) \\
\text { Milrinone } 0.5 \mu \mathrm{g} / \mathrm{kg} / \mathrm{min}(\mathrm{OR} / 1 \mathrm{~d})\end{array}$ & 1.5 units on POD 6 & 0 & 0 & 0 \\
\hline 2 & 64 & None & $\begin{array}{c}2 \text { units on POD } 3 \text {, } \\
1 \text { unit on POD } 5\end{array}$ & 0 & 0 & 0 \\
\hline
\end{tabular}

\begin{tabular}{|c|c|c|c|c|c|c|}
\hline 2 & 37.5 & None & $\begin{array}{l}2 \text { units on POD 1, } \\
1 \text { unit on POD } 5\end{array}$ & 0 & 0 & 0 \\
\hline 3 & 52.5 & $\begin{array}{l}\text { Dopamine } 2 \mu \mathrm{g} / \mathrm{kg} / \mathrm{min}(\mathrm{OR} / 2 \mathrm{~d}) \\
\text { Epinephrine } 0.02 \mu \mathrm{g} / \mathrm{kg} / \mathrm{min}(\mathrm{POD} 2 / 4 \mathrm{~h})\end{array}$ & $\begin{array}{l}1 \text { unit on POD 2, } \\
2 \text { units on POD } 3\end{array}$ & 0 & 0 & 0 \\
\hline 4 & 70 & None & 2 units on POD 3 & 0 & 0 & 0 \\
\hline 5 & 60 & None & 1 unit on POD 1 & 0 & 0 & 0 \\
\hline 6 & 70 & $\begin{array}{l}\text { Milrinone } 0.5 \mu \mathrm{g} / \mathrm{kg} / \mathrm{min}(\mathrm{OR} / 3 \mathrm{~d}) \\
\text { Vasopressin } 0.02 \mathrm{U} / \mathrm{min}(\mathrm{OR} / 3 \mathrm{~h})\end{array}$ & 0 & 0 & 0 & 0 \\
\hline 7 & 23 & Epinephrine 0.08 g/kg/min $(\mathrm{OR} / 1 \mathrm{~d})$ & 1 unit on POD 2 & 0 & 0 & 0 \\
\hline 8 & 66 & $\begin{array}{l}\text { Vasopressin } 0.04 \mathrm{U} / \mathrm{min}(\text { POD } 0 \dagger / 12 \mathrm{~h}) \\
\text { Dopamine } 3 \mu \mathrm{g} / \mathrm{kg} / \mathrm{min}(\mathrm{POD} 0 / 12 \mathrm{~h})\end{array}$ & 0 & 0 & 0 & 0 \\
\hline 9 & 63 & None & 0 & 0 & 2 & 0 \\
\hline 10 & 58 & None & 1 unit on POD 1 & 0 & 0 & 0 \\
\hline 11 & 60 & $\begin{array}{l}\text { Epinephrine } 0.03 \mu \mathrm{g} / \mathrm{kg} / \mathrm{min}(\mathrm{OR} / 12 \mathrm{~h}) \\
\text { Milrinone } 0.5 \mu \mathrm{g} / \mathrm{kg} / \mathrm{min}(\mathrm{OR} / 6 \mathrm{~h})\end{array}$ & 0 & 0 & 0 & 0 \\
\hline 12 & 43 & None & $\begin{array}{l}3 \text { units on POD 1, } \\
2 \text { units on POD } 3\end{array}$ & 0 & 0 & 0 \\
\hline 13 & 68 & $\begin{array}{l}\text { Epinephrine } 0.05 \mu \mathrm{g} / \mathrm{kg} / \mathrm{min}(\mathrm{OR} / 2 \mathrm{~d}) \\
\text { Vasopressin } 0.04 \mathrm{U} / \mathrm{min}(\mathrm{OR} / 2 \mathrm{~d}) \\
\mathrm{IABP}(\mathrm{OR} / 1 \mathrm{~d})\end{array}$ & 1 unit on POD 3 & 0 & 0 & 2 \\
\hline 13 & 68 & See above row & See above row & See above row & See above row & See above row \\
\hline 14 & 62 & None & 2 units on POD 4 & 0 & 0 & 0 \\
\hline 15 & 73 & Epinephrine $0.02 \mu \mathrm{g} / \mathrm{kg} / \mathrm{min}(\mathrm{OR} / 1 \mathrm{~d})$ & 2 units on POD 4 & 0 & 0 & 0 \\
\hline 16 & 49 & $\begin{array}{l}\text { Dopamine } 2 \mu \mathrm{g} / \mathrm{kg} / \mathrm{min}(\mathrm{OR} / 4 \mathrm{~d}) \\
\operatorname{IABP}(\mathrm{OR} / 3 \mathrm{~d})\end{array}$ & 1 unit on POD 5 & 0 & 0 & 0 \\
\hline 16 & 42.5 & Epinephrine $0.05 \mu \mathrm{g} / \mathrm{kg} / \mathrm{min}(\mathrm{OR} / 1 \mathrm{~d})$ & 0 & 0 & 0 & 0 \\
\hline
\end{tabular}

A polyspecific direct antiglobulin test detects the presence of immunoglobulin-G or complement. Specific direct antiglobulin test consists of anti-immunoglobulin-G and anticomplement testing. Test results are graded on a scale of increasing positivity as negative, microscopic positive, weak positive, $1+, 2+, 3+$, and $4+. E F$, Ejection fraction; $I A B P$, intra-aortic balloon pump; $R B C$, red blood cell; $P O D$, postoperative day; poly, polyspecific direct antiglobulin test; $F F P$, fresh-frozen plasma; $L D H$, lactate dehydrogenase; $H b$, hemoglobin; $R R$, reference range; $C T$, chest tube; $C A$, cold agglutinins; $T / D$, total/direct; $w+$, weak positive; $O R$, operating room; $M I$, myocardial infarction. 
APPENDIX TABLE 3. Continued

\begin{tabular}{|c|c|c|c|c|c|c|}
\hline $\begin{array}{c}\text { Hemolysis laboratory studies } \\
\text { (bilirubin mg/dL, haptoglobin mg/dL, } \\
\text { hemoglobin g/dL, LDH U/L) }\end{array}$ & $\begin{array}{c}\text { Hb nadir in } \\
\text { first } 2 \text { d } \\
\text { postoperatively } \\
\text { (g/dL) } \\
\end{array}$ & $\begin{array}{c}\text { CT output in } \\
\text { first } 2 \mathrm{~d} \\
\text { postoperatively (L) } \\
\end{array}$ & $\begin{array}{c}\text { Creatinine peak in } \\
\text { first } 2 \mathrm{~d} \text { postoperatively } \\
(\mathbf{m g} / \mathbf{d L})\end{array}$ & $\begin{array}{c}\text { Postoperative } \\
\text { MI } \\
\end{array}$ & $\begin{array}{c}\text { Hospital } \\
\text { length } \\
\text { of stay (d) }\end{array}$ & $\begin{array}{c}\text { Death within } \\
30 \mathrm{~d} \\
\end{array}$ \\
\hline $\begin{array}{l}\text { POD 6: haptoglobin }<14, \mathrm{LDH} 351, \\
\text { poly negative, CA titer } 128, \\
\text { bilirubin T/D } 1.2 / 0.3\end{array}$ & 9.9 & 1 & 1.1 & No & 18 & No \\
\hline $\begin{array}{l}\text { POD 2: poly w+ } \\
\text { POD 3: LDH 551, bilirubin T/D 7.3/2.2 } \\
\text { POD 4: poly } 2+, \text { LDH 585, bilirubin } \\
8.7 / 4\end{array}$ & 8.6 & 0.46 & 0.8 & No & 6 & No \\
\hline $\begin{array}{l}\text { POD 5: poly } 1+\text {, LDH 568, bilirubin } \\
\text { T/D 6.5/2.4 }\end{array}$ & & & & & & \\
\hline POD 6: bilirubin 6.1/1.5 & & & & & & \\
\hline $\begin{array}{l}\text { POD 5: poly } 1+\text {, plasma } \mathrm{Hb} 42.4 \\
\text { (RR 0-15), haptoglobin }<14, \\
\text { bilirubin T/D 4.3/1.4, LDH } 458\end{array}$ & 8.8 & 2.4 & 0.5 & No & 6 & No \\
\hline $\begin{array}{l}\text { POD 3: poly weak }+ \\
\text { No other hemolysis laboratory tests } \\
\text { drawn }\end{array}$ & 8.3 & 0.31 & 1.5 & No & 6 & No \\
\hline $\begin{array}{l}\text { POD 4: Haptoglobin } 29, \text { LDH } 366, \\
\text { bilirubin } 2.4 / 0.5, \text { CA screen } \\
\text { positive, CA titers } 65,536\end{array}$ & 8.4 & 0.79 & 0.8 & No & 6 & No \\
\hline $\begin{array}{l}\text { POD 2: CA screen positive, titers }>512 \\
\text { No other hemolysis testing done }\end{array}$ & 8.6 & 0.89 & 0.9 & No & 5 & No \\
\hline No hemolysis testing done & 10.4 & 0.9 & 1.1 & No & 7 & No \\
\hline No hemolysis testing done & 8.8 & 0.88 & 2 & No & 5 & No \\
\hline No hemolysis testing done & 9.9 & 1.27 & 0.7 & No & 5 & No \\
\hline No other hemolysis testing done & 10 & 1.21 & 1 & No & 5 & No \\
\hline No hemolysis testing done & 9.1 & 1.3 & 1.2 & No & 4 & No \\
\hline No hemolysis testing done & 9.2 & 2.8 & 0.9 & No & 7 & No \\
\hline No hemolysis testing done & 8 & 1.5 & 1.2 & No & 5 & No \\
\hline $\begin{array}{l}\text { POD 4: bilirubin T/D 1.3/0.4, LDH } 495 . \\
\text { POD 6: bilirubin T/D 1/0.4 LDH } 428 .\end{array}$ & 9.4 & 1.65 & 1.7 & No & 10 & No \\
\hline See above row & See above row & See above row & See above row & No & $\begin{array}{l}\text { See above } \\
\text { row }\end{array}$ & No \\
\hline $\begin{array}{l}\text { POD 4: poly } 1+ \\
\text { No other hemolysis testing done }\end{array}$ & 8.9 & 0.54 & 1.7 & No & 5 & No \\
\hline POD 4: poly w + & 9 & 0.94 & 1 & No & 5 & No \\
\hline No hemolysis testing done & 10.4 & 1.1 & 1.3 & No & 10 & No \\
\hline No hemolysis testing done & 11.3 & 0.8 & 1 & No & 11 & No \\
\hline
\end{tabular}




\section{APPENDIX 4. METHOD OF COLD AGGLUTININS ANTIBODY TITER DETERMINATION}

The CA antibody titer is performed on serum or plasma. The samples are collected and maintained at $37^{\circ} \mathrm{C}$. For serum samples, the blood is allowed to clot at $37^{\circ} \mathrm{C}$, whereas for plasma samples, the plasma is separated from the whole blood at $37^{\circ} \mathrm{C}$. Serial dilutions are made of the sample using phosphate-buffered saline. This is tested against 2 drops of $3 \%$ to $5 \%$ suspension of pooled group $\mathrm{O}$ red blood cells. The cells are incubated in the dilutions at $4^{\circ} \mathrm{C}$ for 1 to 2 hours. They are then centrifuged and stored in a rack in an ice water bath until read. ${ }^{13}$ 